\title{
LANDASAN DAN IMPLEMENTASI PENDIDIKAN MULTIKULTURAL DI INDONESIA
}

Oleh:

Rukiyati

FIP UNY

\begin{abstract}
Abstrak
Pendidikan multikultural adalah sebuah ide, pendekatan untuk perbaikan sekolah dan gerakan kesetaraan, keadilan sosial dan demokrasi. Pendidikan multikultural menekankan komponen dan kelompok budaya yang beragam, tetapi dapat dibangun konsensus berupa penghargaan pada prinsip-prinsip utama, konsepkonsep dan tujuan. Tujuan utama pendidikan multikultural adalah untuk merestrukturisasi sekolah sehingga semua siswa memperoleh pengetahuan, sikap dan keahlian yang dibutuhkan dalam memfungsikan bangsa dan dunia yang secara etnis dan ras berbeda.
\end{abstract}

Kata kunci: pendidikan multikultural, sekolah.

\section{Pendahuluan}

Pendidikan multikultural adalah sebuah ide, pendekatan untuk perbaikan sekolah dan gerakan kesetaraan, keadilan sosial dan demokrasi. Para ahli pendidikan multikultural menekankan komponen dan kelompok budaya yang beragam, tetapi mereka mempunyai konsensus berupa penghargaan pada prinsipprinsip utama, konsep-konsep dan tujuan. Tujuan utama pendidikan multikultural adalah untuk merestrukturisasi sekolah sehingga semua siswa memperoleh pengetahuan, sikap dan keahlian yang dibutuhkan dalam memfungsikan bangsa dan dunia yang secara etnis dan ras berbeda-beda. Pendidikan multikultural menginginkan jaminan kesetaraan pendidikan bagi anggota ras yang berbeda, etnis, budaya dan kelompok sosio-ekonomi dan untuk memfasilitasi partisipasi mereka sebagai warganegara yang kritis dan reflektif dalam sebuah budaya nasional kebangsaan yang inklusif ( Zamroni, 2008: 292).

Landasan ontologis pendidikan multikultural adalah pluralisme. Pluralisme sekarang ini merupakan ide yang hampir universal di seluruh dunia. Sebagaimana dinyatakan oleh Nikolas Gvosdev (Zamroni, 2008: 105) bahwa berbagai gelombang demokratisasi yang terjadi di berbagai bagian dunia selama tiga puluh tahun terakhir secara mendasar telah mengubah dialog internasional tentang hak asasi. Pluralisme menjadi mode dan sekaranglah zaman kemenangan pluralisme terhadap 
otoritarianisme, zaman kemenangan kemanusiaan dan diversifikasi sumber-sumber kreativitas. Setiap warga negara mempunyai kebebasan memilih apa yang dipikirkannya, agama, keyakinan dan gaya hidupnya. Negara totaliter tinggal sedikit dan terdengar kuno di dunia sekarang ini.

Seiring dengan mendunianya pluralisme, pendidikan multikultural merupakan isu penting yang hangat diwacanakan sekarang seiring dengan meningkatnya kesadaran orang akan persamaan derajat dan kebebasan manusia. Tidak terkecuali Indonesia, sebagai sebuah negara yang didirikan dengan konsep modern dan secara kultural bersifat terbuka terhadap berbagai ide dan perubahan dunia. Sejak lama telah disadari bahwa Indonesia adalah bangsa yang multikultural, baik ditinjau dari aspek adat-istiadat dan budaya, sosial-ekonomi juga agama. Semboyan bhinneka tunggal Ika adalah bukti yang menunjukkan adanya pengakuan keberagaman itu. Banyak para pengamat dari luar yang kagum terhadap keberagaman Indonesia. Salah satunya adalah sebagaimana digambarkan oleh Robert Gribb (2002:3):

"Memandang peta rasanya cukup untuk memberi kesan tidak mungkin mengenai adanya Negara Indonesia. Dengan lebih dari 13.000 pulau, yang terbentang dari barat ke timur sepanjang lebih dari $5.000 \mathrm{~km}$ melintasi tiga zona waktu, Indonesia merupakan negara kepulauan terbesar di dunia. Orang akan menduga bahwa di sekumpulan pulau yang banyak itu sekurangkurangnya terdapat beberapa negara. Tetapi, ternyata hanya ada satu, Republik Indonesia. Di sisi lain, keheranan akan adanya satu Indonesia, hanyalah timbul di hati orang pemandang peta. Bagi presiden pertama negara ini, Sukarno, kesatuan Indonesia bukanlah suatu anomali; itu sudah ditakdirkan."

Ditinjau dari sisi sosio-kultural, kehidupan di Indonesia menunjukkan adanya keberagaman yang sangat kaya. Sebagian besar dari 237 juta jiwa lebih orang Indonesia mengidentifikasikan dirinya dengan salah satu dari 200 kelompok etnis lebih yang terbentang dari suku Jawa, dengan kurang lebih 100 juta jiwa, yang mendiami pulau Jawa sampai ke komunitas-komunitas bahasa yang semakin lenyap di kepulauan Indonesia Timur sebelah timur Sulawesi. Mayoritas terbesar orang Indonesia yang hidup sekarang adalah keturunan kaum migrant Austronesia ke pulau-pulau ini, yang mulai berpindah ke selatan dari daerah yang sekarang disebut Taiwan kira-kira 5.500 tahun yang lalu. Mereka melakukan pelayaran dalam 
perahu-perahu gandung yang kuat, dan migrasi ini tidak hanya membawa mereka ke kepulauan Filipina dan Indonesia, tetapi juga sampai ke Pasifik, di mana mereka menjadi nenek moyang orang Polinesia modern, dan melintasi Lautan India ke Madagaskar, yang rakyatnya terutama masih keturunan Austronesia. Mereka menetap di pulau-pulau kosong dan pesisir yang tidak berpenghuni. Di lain pihak, di pulau Papua dan pulau-pulau sekitarnya di sebelah barat, seperti Timor, orang Melanesia telah hidup beribu-ribu tahun lamanya dengan cirri khas masyarakat pemburu.

Dewasa ini di Indonesia, orang keturunan Austronesia masih tetap dapat dibedakan dari sesama warga mereka keturunan Melanesia. Kebanyakan orang Melanesia, yang terkonsentrasi di kawasan paling timur, berkulit hitam dan berambut keriting, serta memiliki bahasa yang berbeda dari orang Indonesia keturunan Austronesia yang jumlahnya lebih besar, berkulit coklat dan berambut lurus. Perbedaan-per bedaan ini, antara pulau Jawa dan pulau-pulau di kawasan barat lainnya di satu pihak, dengan pulau-pulau di kawasan timur di pihak lainnya, tetap tercermin dalam konflik politik baik yang telah selesai (Timor Timur) maupun yang masih berlangsung ibarat api dalam sekam, yang secara terang-terangan dimotori oleh Gerakan Papua Merdeka.

Ditinjau dari sisi ekonomi, Indonesia termasuk negara yang masih berkembang. Sejak zaman kolonialisme Belanda, sebagaimana dikatakan oleh Burke bahwa ekonomi Indonesia bersifat dualisme, di satu pihak ada kelompok atas yang jumlah kecil, tetapi menguasai kegiatan sebagian besar kegiatan ekonomi dari hulu sampai hilir. Di pihak lain ada kelompok bawah yang sangat besar, tetapi hanya menguasai kegiatan ekonomi skala kecil dan menengah. Demikian pula, ketika zaman Orde Baru, kebijakan pemerintah memang memberikan keleluasaan dan kesempatan yang lebih besar kepada para pelaku ekonomi kelas kakap dengan harapan akan adanya trickle down effect. Kenyataan yang terjadi justru sebaliknya, ketika krisis moneter mengguncang Indonesia pada paruh kedua 1997, justru para pelaku ekonomi kelas kakap atau konglomerat ini yang membebani negara dengan beban hutang yang tak-dapat dibayar bahkan sampai sekarang. Sedangkan para pelaku ekonomi kelas menengah ke bawah justru dapat tetap bertahan di era krisis, walaupun tidak banyak memperoleh fasilitas dari negara. Bukti ini telah 
menyadarkan pemerintah sekarang bahwa usaha kecil dan menengah adalah usaha yang dapat diandalkan dan harus dibantu untuk dapat berkembang, tetapi realisasinya belum begitu mengesankan.

Adanya krisis ekonomi berakibat pada berbagai krisis dalam kehidupan bangsa, terutama krisis politik yang berujung pada tekad untuk mereformasi berbagai bidang kehidupan berbangsa-bernegara sesuai dengan format baru dengan kata kunci: demokratisasi, di antaranya yang menonjol adalah reformasi politik, reformasi hukum dan reformasi pendidikan. Demokratisasi mulai tampak implementasinya dalam berbagai bidang kehidupan berbangsa bernegara. Salah satu bentuknya adalah adanya pergeseran dari sentralisasi kekuasaan di pusat kepada desentralisasi berupa otonomi daerah. Proses demokratisasi yang berlangsung relatif cepat memerlukan kesigapan untuk beradaptasi dari segenap warga bangsa. Demokratisasi kalau tidak dimaknai dengan hati-hati akan membawa perubahan radikal yang akhirnya akan meruntuhkan segi-segi kehidupan berbangsa-bernegara. Fenomena ini telah tampak beberapa tahun terakhir dengan menguatnya kembali sikap-sikap dan gerakan separatisme untuk memisahkan diri dari Indonesia. Memang hal ini sedikit banyak juga dipicu oleh adanya sentralisasi kekuasaan yang sangat ketat. Maka, setelah reformasi pendulum justru mengarah kepada sisi yang lain, bukan sentralisasi melainkan semangat serba otonomi, dimulai dengan adanya otonomi daerah yang diatur pertama kali dalam UU Nomor 22 Tahun 1999 dan diperbaiki dalam UU Nomor 34 Tahun 2002.

Sebagaimana diketahui bahwa otonomi daerah membawa berbagai implikasi dalam bidang, tidak terkecuali pendidikan. Beberapa tahun terakhir telah terjadi pergeseran yang cukup signifikan dari sentralisasi kebijakan pendidikan kepada desentralisasi yang terwujud dalam otonomi daerah, maupun dalam otonomi sekolah. Setiap level dalam pengelolaan pendidikan mempunyai wewenangnya sendiri yang telah diatur dalam peraturan perundang-undangan.

Dengan mengingat keberagaman Indonesia dan adanya pergeseran politik yang terarah pada desentralisasi itu membawa konsekuensi tersendiri bagi praksis pendidikan di Indonesia. Bila dikaitkan dengan konsep dasar pendidikan multikultural sebagaimana dinyatakan di atas, maka Indonesia perlu menata praksis pendidikan multikultural yang sesuai dengan konteks kesejarahannya dan 
idealisasi masa depan. Pertanyaannya adalah: Apa yang menjadi landasan dasar pendidikan multikultural di Indonesia? Bagaimana implementasi pendidikan multikultural di sekolah? Inilah pertanyaan pokok yang akan dicoba dibahas dalam makalah singkat ini.

\section{Pembahasan}

\section{Pendidikan multikultural berlandaskan filsafat bangsa: Pancasila}

Pendidikan multikultural adalah konsep yang umum sekarang ini, walaupun awalnya muncul sebagai idealisasi pendidikan, karena adanya diskriminasi ras yang sangat tidak berperikemanusiaan dan kesejangan social-politik-ekonomi yang sangat tajam di Amerika Serikat. Sebagaimana diketahui, Amerika Serikat yang bersuara lantang mempromosikan demokrasi dan hak asasi manusia ke seluruh dunia, kalau perlu dengan kekuatan senjata, justru di dalam negerinya sendiri tidak dapat melaksanakan ide-ide besarnya secara konsekuen. Perlakuan yang tidak manusiawi terhadap warga Negara keturunan Afro-Amerika selama berabad-abad bahkan sampai abad XX.

Penelitian etnografis Jonathan Kozol (Noel, 2007) menyimpulkan adanya ketidakadilan yang kejam dari pemerintah AS yang didominasi orang kulit putih terhadap orang-orang kulit hitam. Melalui bukunya yang banyak mengenai kondisi sekolah dan komunitas kulit hitam, khususnya yang miskin, Jonathan Kozol membawa perhatian kita pada perjuangan dan harapan dari anak-anak yang terlewatkan di dalam masyarakat Amerika Serikat. Ia menaruh perhatian pada segregasi rasial yang ekstrem di sekolah-sekolah Amerika dan perbedaan yang berhubungan dengan pengabaian dalam hal pendanaan, keselamatan dan kualitas sekolah. Ia menggunakan pendekatan etnografis, dengan menghabiskan waktunya bersama komunitas yang ditelitinya. Karyanya ini langsung ditujukan pada hal-hal yang berkaitan dengan kemiskinan, tunawisma, dan ketidaksamaan pendidikan yang dialami kelompok masyarakat kulit hitam Amerika. Hal ini membuktikan bahwa Amerika bersifat ambigu dalam menerapkan ide-ide demokrasinya. Walaupun takdapat dinafikan sekarang ini mereka mulai menata kembali kehidupan berbangsanya secara lebih adil dan manusiawi dibuktikan dengan terpilihnya Barack Obama sebagai presiden kulit hitam pertama AS. 
Akan halnya Indonesia, walaupun dari sisi sosio-kultural ada persamaannya dengan Amerika Serikat, yaitu sama-sama multi-etnis, multi-agama dan bahasa, tetapi dari sisi lain tampak pula perbedaan yang sangat menonjol. Amerika dikenal sebagai negara tempat impian para imigran dari berbagai belahan dunia yang sekarang termasuk negara maju yang telah berdiri hampir 300 tahun lamanya. Secara historis, Amerika telah mengalami perang sipil dan diskriminasi ras yang seakan "dilegalkan” negara. Sedangkan Indonesia adalah negara muda yang berusia hampir 64 tahun, didirikan dengan perjuangan yang menggelora dari para penggerak kemerdekaan melawan kolonialisme dilandasi semangat persatuan bangsa. Dengan demikian, tentu saja ada perbedaan-perbedaan dalam hal pandangan-pandangan ideal dan upaya mewujudkannya. American dream tentu tidak sama basisnya dengan mimpi Indonesia adil dan makmur. Di samping itu ada pula hal-hal yang dapat berlaku universal, ide-ide dasar di Amerika Serikat dapat pula diterapkan di Indonesia apabila memang menunjukkan adanya kemashlahatannya bagi bangsa Indonesia sepanjang tidak bertentangan dengan prinsip-prinsip dasar hidup bermasyarakat dan bernegara.

Amerika Serikat mendasarkan pendidikan multikulturalnya pada prinsipprinsip persamaan hak asasi manusia dan kebebasan (liberalisme) sebagai warisan sejarah peradaban barat yang modern dan sekuler. Indonesia mendasarkan pada nilai-nilai Pancasila yang bersifat humanis-religius sebagai nilai idealnya dalam segenap gerak langkah kehidupan berbangsa bernegara, termasuk dalam pendidikan.

Sebagaimana diketahui nilai-nilai Pancasila yang pertama kali dirumuskan dan diperkenalkan oleh Ir. Soekarno sebagai salah satu the founding fathers Indonesia pada sidang BPUPKI 1 Juni 1945 dengan rumusan: Kebangsaan (nasionalisme), kemanusiaan (internasionalisme), musyawarah-mufakat (demokrasi), kesejahteraan rakyat dan ketuhanan yang berkebudayaan. Setelah itu diadakan penyesuaian rumusan dari Panitia Kecil yang berjumlah Sembilan orang (Panitia Sembilan) sehingga pada tanggal 22 Juni 1945 disepakati rumusan Pancasila sebagaimana tercantum dalam Rancangan Preambule Hukum Dasar yang popular dengan nama Piagam Jakarta yang mengeksplisitkan kewajiban menjalankan syariat Islam bagi pemeluk-pemeluknya sebagai keterangan lanjut dari sila pertama (Ketuhanan). Setelah terjadi negosiasi karena adanya keberatan dari 
wakil-wakil Indonesia bagian timur, sidang PPKI tanggal 18 Agustus dengan agenda pertama mengesahkan UUD RI memutuskan menghapus tujuh kata dalam sila pertama: "Ketuhanan dengan kewajiban menjalankan syariat Islam bagi pemelukpemeluknya" dan diganti dengan rumusan: "Ketuhanan Yang Maha Esa" sehingga rumusan Pancasila menjadi: Ketuhanan Yang Maha Esa, kemanusiaan yang adil dan beradab, persatuan Indonesia, kerakyatan yang dipimpin oleh hikmat kebijaksanaan dalam permusyawaratan/perwakilan serta keadilan social bagi seluruh rakyat Indonesia (Risalah Sidang BPUPKI-PPKI, 1995). Inilah nilai-nilai ideal yang harus diwujudkan oleh segenap komponen bangsa, baik pemerintah maupun rakyat biasa. Maka, logislah bila sebagaimana termaktub di dalam Undang-Undang Nomor 20 Tahun 2003 tentang Sistem Pendidikan Nasional bahwa pendidikan berlandaskan pada Pancasila.

Pernyataan tersebut bukan hanya rangkaian kata-kata yang menjadi teks mati dalam Undang-Undang, melainkan harus diwujudkan dalam praksis pendidikan yang sesungguhnya. Demikian pula dalam hal pendidikan multikultural seyogyanya ada kesejalanan antara praktik dan dasar teoritiknya (praksis) yang berlandaskan nilai-nilai Pancasila. Perlu pula dirumuskan dengan jelas apa yang menjadi tujuan pendidikan multicultural di Indonesia.

Sebagaimana dinyatakan oleh Tilaar (2004:192) pendidikan multikultural di Indonesia bertujuan untuk membina pribadi-pribadi Indonesia yang mempunyai kebudayaan sukunya masing-masing, memelihara dan mengembangkannya, serta sekaligus membangun bangsa Indonesia dengan kebudayaan Indonesia sebagaimana diamanatkan di dalam Undang-Undang Dasar 1945. Acuan untuk merumuskan pendidikan multikultural di Indonesia adalah pertama-tama hendaknya dilihat realitas kehidupan bangsa Indonesia yang beragam suku dan kebudayaannya itu. Kebudayaan masing-masing suku itu merupakan milik yang sangat berharga bagi individu dan bagi bangsa Indonesia. Bagi individu, kebudayaan suku bangsanya merupakan kekayaan rohaniah, di mana individu berkembang sebagai seorang pribadi, dan sekaligus dijadikan pijakan untuk membangun kebudayaan Indonesia yang dicita-citakan.

Kenyataan akan kebhinnekaan budaya dan masyarakat Indonesia telah disadari sepenuhnya oleh para bapak bangsa ketika hendak mendirikan Negara 
Indonesia. Selain Ir. Soekarno, Mr. Soepomo juga telah berpidato di depan sidang BPUPKI pada tanggal 31 Mei 1945 tentang Negara persatuan yang bersifat integralistik. Ini merupakan bukti bahwa kesadaran kebhinnekaan itu telah ada dalam diri para pemimpin bangsa tersebut. Kenyataan akan kebhinnekaan budaya dan masyarakat Indonesia dijamin di dalam Undang-Undang Dasar 1945 dan dinyatakan semboyan kita: Bhinneka Tunggal Ika. Inilah yang menjadi dasar perumusan pendidikan multikultural Indonesia (Tilaar, 2004:193).

Memang semasa Orde Baru semangat kebhinnekaan agak bergeser menjadi semangat mengindonesiakan budaya suku tertentu, agar diterima sebagai mainstream seluruh masyarakat Indonesia, sehingga menimbulkan rasa curiga dan ketidakpuasan dari berbagai daerah, terutama yang merasa dianaktirikan. Untunglah seiring dengan reformasi di berbagai bidang, hal tersebut perlahan-lahan telah dikoreksi.

Di samping menghadapi masalah internal, Indonesia juga menghadapi kekuatan-kekuatan global yang melanda kehidupan umat manusia dewasa ini. Sebagaimana dinyatakan oleh John Naisbitt bahwa globalisasi membawa kehidupan pada situasi yang disebutnya global paradox. Di satu sisi, globalisasi dapat memperkuat kekuatan-kekuatan global yang menghilangkan identitas suatu bangsa, yang dalam jangka panjang berakibat hilangnya kebudayaan yang unik dari masingmasing kelompok manusia. Di pihak lain, globalisasi telah pula membangkitkan sentimen-sentimen lokal dan kesukuan, yang menimbulkan rasa menghargai kebudayaan lokal sebagai modal untuk memperkuat harga diri seseorang agar tidak hanyut di dalam arus penyamarataan global. Fenomena ini tampak juga di Indonesia, pengaruh globalisasi telah mencengkram Indonesia terutama dari sisi ekonomi yang menjadi salah satu sasaran utama kapitalisme global. Di sisi lain, adanya otonomi daerah dan sentimen kepada hal-hal yang primordial telah memunculkan penguasapenguasa baru di daerah dengan kekuasaan yang besar pula sehingga dapat beresiko munculnya negara dalam Negara Indonesia. Kekuatan global yang bersifat mondial, di satu sisi dan kekuatan lokal yang bersifat kedaerahan di lain pihak, diprediksi akan mempersulit terwujdnya negara bangsa yang kuat, adil, makmur dan merata. Maka, diperlukan respons yang tepat di dalam pembinaan generasi yang akan 
datang. Oleh sebab itu, pendidikan multikultural merupakan suatu tuntutan di dalam pengembangan sumber daya manusia Indonesia (Tilaar, 2004: 194).

Jadi, pendidikan multikultural merupakan suatu keniscayaan, dengan bertitik tolak dari budaya bangsa yang bhinneka tunggal ika dengan dasar Pancasila, dengan tujuan umum untuk mewujudkan masyarakat Indonesia yang egaliter dan sejahtera.

\section{Implementasi Pendidikan Multikultural di Sekolah}

Implementasi pendidikan multikultural dapat dilakukan dalam berbagai aspek dan kelembagaan. Tilaar (2004:224) menawarkan lima program prioritas pendidikan multikultural, yakni lembaga-lembaga pendidikan sebagai pusat budaya, pendidikan kewargaan, kurikulum pendidikan multikultural, kebijakan perbukuan dan pendidikan guru. Ide-ide Tilaar tersebut merupakan konsep makro yang bersifat menyeluruh. Tetapi, pada kesempatan kali ini penulis membatasi hanya pada implementasi pendidikan multikultural di sekolah, meliputi tiga hal, yaitu kultur sekolah, manajemen sekolah dan proses pembelajaran.

1. Kultur sekolah

Kultur merupakan pandangan hidup yang diakui bersama oleh suatu kelompok masyarakat, yang mencakup cara berfikir, perilaku, sikap, nilai yang tercermin baik dalam ujud fisik maupun abstrak. Kultur ini juga dapat dilihat sebagai suatu perilaku, nilai-nilai, sikap hidup, dan cara hidup untuk melakukan penyesuaian dengan lingkungan, dan sekaligus cara untuk memandang persoalan dan memecahkannya. Oleh karena itu, suatu kultur secara alami akan diwariskan oleh satu generasi kepada generasi berikutnya. Sekolah merupakan lembaga utama yang yang didesain untuk memperlancar proses transmisi kultural antar generasi tersebut.

Dalam dunia pendidikan, semula kultur suatu bangsa (bukan kultur sekolah) yang diduga sebagai faktor yang paling menentukan kualitas sekolah. Tetapi berbagai penelitian menemukan bahwa pengaruh kultur bangsa terhadap prestasi pendidikan tidak sebesar yang diduga selama ini. Bukti terakhir, hasil TIMSS (The Third international Math and Science Study) menunjukkan bahwa siswa dari Jepang, dan Belgia sama-sama menempati pada rangking atas untuk mata pelajaran matematika, padahal kultur negara-negara tersebut berbeda. Oleh karena itu, para 
peneliti pendidikan lebih memfokuskan pada kultur sekolah, bukannya kultur masyarakat secara umum, sebagai salah satu faktor penentu kualitas sekolah. Tesis ini sesuai dengan temuan-temuan mutakhir penelitian di bidang pendidikan yang menekankan bahwa "faktor penentu kualitas pendidikan tidak hanya dalam wujud fisik, seperti keberadaan guru yang berkualitas, kelengkapan peralatan laboratorium dan buku perpustakaan, tetapi juga dalam wujud non-fisik, yakni berupa kultur sekolah". Secara singkat dapat dinyatakan bahwa kultur sekolah adalah pola nilainilai, norma-norma, sikap, ritual, mitos dan kebiasaan-kebiasaan yang dibentuk dalam perjalanan panjang sekolah. Kultur sekolah dipegang bersama baik oleh kepala sekolah, guru, staf administrasi maupun siswa, sebagai dasar mereka dalam memahami dan memecahkan berbagai persoalan yang muncul di sekolah.

Pengaruh kultur sekolah atas prestasi siswa di Amerika Serikat telah dibuktikan lewat penelitian empiris. Kultur yang "sehat" memiliki korelasi yang tinggi dengan:

a) prestasi dan motivasi siswa untuk berprestasi,

b) sikap dan motivsi kerja guru,

c) produktivitas dan kepuasan kerja guru.

Namun demikian, analisis kultur sekolah harus dilihat sebagai bagian suatu kesatuan sekolah yang utuh. Artinya, sesuatu yang ada pada suatu kultur sekolah hanya dapat dilihat dan dijelaskan dalam kaitan dengan aspek yang lain, seperti, a) rangsangan untuk berprestasi, b) penghargaan yang tinggi terhadap prestasi, c) komunitas sekolah yang tertib, d) pemahaman tujuan sekolah, e) ideologi organisasi yang kuat, f) partisipasi orang tua siswa, g) kepemimpinan kepala sekolah, dan, h) hubungan akrab di antara guru. Dengan kata lain, dampak kultur sekolah terhadap prestasi siswa meskipun sangat kuat tetapi tidaklah bersifat langsung, melainkan lewat berbagai variabel, antara lain seperti semangat kerja keras dan kemauan untuk berprestasi.

Di Indonesia belum banyak diungkap penelitian yang menyangkut kultur sekolah dalam kaitannya dengan prestasi siswa. Tetapi, mengingat bahwa sekolah sebagai suatu sistem di manapun berada adalah relatif sama, maka hasil penelitian di Amerika Serikat tersebut perlu mendapatkan perhatian, paling tidak dapat dijadikan jawaban hipotetis bagi persoalan pendidikan kita. Artinya, kita perlu membangun 
kultur sekolah yang sehat agar dapat meningkatkan prestasi belajar siswa sebagai salah satu upaya kongkrit pelaksanaan pendidikan multikultural di Indonesia.

Kultur sekolah yang memungkinkan bagi tercapainya kesuksesan belajar siswa dari berbagai latar belakang yang berbeda perlu dirancang sedemikian rupa, sehingga sekolah menjadi komunitas yang mencerminkan living values yang ditetapkan bersama. Sejak lama sekolah-sekolah di Indonesia kehilangan sense of identity, sense of belonging, sense of community dan sense of cooperative. Sekolah hanya tempat belajar pengetahuan yang sifatnya cenderung transaksional, di dalamnya guru dan kepala sekolah hanya sebagai pengelola dan penyedia ilmu yang dibeli oleh siswa sebagai konsumennya. Hilangnya identitas diri sebagai pelajar yang sedang menuntut ilmu dan kebersamaan sebagai warga sekolah telah membawa akibat-akibat yang negatif seperti sikap tidak peduli, minimnya komunikasi antara guru dan murid sehingga berakibat pada hilangnya rasa saling memilki terhadap keberadaan sekolah dan pada gilirannya hilang pula solidaritas dan kerja sama antar warga sekolah. Sebaliknya, para siswa membentuk wadah komunikasi sendiri yang bersifat liar dan destruktif dengan membentuk gank-gank. Itulah yang terjadi di Bandung dengan gank motornya, di Pati dengan gank Nero (Neko-neko royok), di Jakarta dan Yogya yang terkenal dengan tawuran antarsekolah. Jika keadaan ini tidak segera disadari dan diperbaiki, maka para pelajar kita akan semakin jauh dapat melaksanakan pendidikan multikultural.

Berkaitan dengan masalah di atas, hal yang dapat dilakukan adalah membenahi dan menumbuhkan kultur sekolah yang kondusif bagi pembelajaran multikultural adalah dengan cara sebagai berikut: a) Tumbuhkan rasa bangsa dengan identitas pelajar sebagai siswa di sekolah tersebut; b) Jalin komunikasi yang efektif di antara warga sekolah, baik guru, siswa, staf sekolah maupun orang tua dan komite sekolah; c) Sosialisasikan visi dan misi sekolah berulang-ulang dengan berbagai media yang mudah dipahami siswa, misalnya dengan tulisan-tulisan yang menyentuh hati nurani dan kesadaran human seluruh warga sekolah; d) Diadakan kegiatan di luar sekolah yang mengarah pada kerjasama dan kebersamaan antara siswa dan guru. Dengan upaya-upaya tersebut diharapkan akan terwujud kultur sekolah yang humanistik dan menghargai keragaman. 


\section{Manajemen sekolah}

Sekolah yang hendak mewujudkan tujuan kesempatan dan kesetaraan dalam belajar sebagaimana yang menjadi fokus pendidikan multikultural haruslah dikelola dengan kepemimpinan kepala sekolah yang kuat. Kepala sekolah tidak hanya sebagai manajer, melainkan lebih dari itu. Ia harus menjadi leader (pemimpin). Pemimpin yang baik sebagaimana dinyatakan oleh John Kotler (1996:17-32) adalah yang mempunyai kepekaan terhadap kemendesakan (sense of urgency), menciptakan koalisi yang memimpin perubahan, mengembangkan visi dan strategi, mengkomunikasikan visi, memberdayakan bawahan untuk aksi yang luas, mengakumulasikan keberhasilan demi keberhasilan, merayakan keberhasilan dan menghasilkan keberhasilan baru, serta menancapkan pendekatan baru dalam budaya organisasi.

Sebaliknya, kepala sekolah yang lebih cnderung bertindak sebagai manajer sering terjebak dalam manajerialisme. Manajerialisme dalam konteks ini diartikan sebagai perhatian berlebihan terhadap sistem dan struktur dalam hal yang merusak tujuan inti organisasi. Keharusan birokratis sering dicatat sebagai salah satu sasaran utama dari strategi manajemen mutu, dan itu mudah untuk menjelaskan alasannya. Berkas yang tebal dari standar prosedur operasi terlihat jauh sekali dari kegembiraan belajar dan kreativitas pengajaran. Apa yang trerjadi adalah bahwa sekolah lebih mudah untuk mengelola prosedur rutin daripada memberikan kepemimpinan untuk menciptakan kultur perubahan yang kontinyu ( Tony Bush \& Les Bell, 2006: 145).

Dengan adanya otonomi sekolah di era desentralisasi sekarang ini, kepemimpinan kepala sekolah mempunyai peran penting untuk mewujudkan tujuan pendidikan multikultural. Kepala sekolah yang dapat melaksanakan delapan tahap sebagaimana dinyatakan Kotler di atas diprediksi akan berhasil dalam mewujudkan tujuan tersebut. Prinsip kesempatan yang sama di satu sisi dan kesetaraan di pihak lain harus menjadi pedoman kepala sekolah dalam membimbing para guru dan staf sehingga siswa yang berasal dari latar belakang sosial-ekonomi dan budaya yang terpinggirkan mendapatkan perhatian yang lebih agar dapat mencapai standar kesuksesan yang telah ditetapkan. Sementara itu, siswa yang telah mempunyai keberuntungan karena perbedaan kultur dan tingkat sosial-ekonomi orang tua 
diberikan pengertian dan kepekaan untuk saling memahami, saling membantu dan saling peduli kepada teman-temannya yang kurang beruntung.

Sekolah juga hendaknya menciptakan kesempatan dan kegiatan yang memungkinkan siswa dapat memiliki kecakapan hidup (life skills) yang mengarah pada dikuasainya ketrampilan tertentu (pekerjaan tangan, kerajinan) untuk dapat sebagai bekal mencari nafkah, ketika para siswa yang kurang beruntung ini tidak bersekolah lagi, karena keterbatasan yang dimilikinya. Bagi siswa yang beruntung secara sosial ekonomi, life skills berguna pula bagi hidupnya, setidaknya dengan dikuasainya ketrampilan tertentu ia akan dapat menghargai pekerjaan tangan yang selama ini sering dipandang rendah.

\section{Proses pembelajaran}

Dimensi penting dalam pendidikan adalah proses pembelajaran. Pembelajaran yang mendukung untuk mencapai tujuan pendidikan multikultural adalah pembelajaran yang berdasarkan pada pedadogik transformatif. Pedagogik transformatif adalah pedagogik yang mengungkapkan kebebasan dan sekaligus keterbatasan manusia, serta menekankan pentingnya partisipasi dengan sesama manusia. Partisipasi dengan sesama manusia menuntut tindakan-tindakan atau kelakuan yang mau menerima sesama manusia sebagaimana adanya. Tanggung jawab, toleransi, kerja sama , saling membantu, saling menghormati pendapat orang lain dan berbagai sikap dan serta kelakukan manusia yang memperkuat kerja sama, merupakan nilai-nilai yang mendapatkan prioritas di dalam proses pembelajaran yang berlandaskan pedagogik transformatif. Di samping itu, pedagogik transformatif juga mengungkapkan keterbatasan manusia, implisit di dalamnya mengandung pengakuan akan kebesaran Sang Pencipta (Tilaar, 2002:152-153).

Proses pembelajaran di Indonesia sekarang ini kurang berdimensi sosial, karena lebih memperhatikan pada kesuksesan individu. Persaingan dipandang sebagai hal yang sehat agar dapat menjadi pemenang (sukses belajar). Semua itu sebenarnya adalah cara-cara belajar yang didasarkan pada filsafat individualisme dan liberalisme. Dalam konteks Indonesia, proses pembelajaran harus dilandasi semangat interdependensi, saling ketergantungan dan saling membutuhkan. Prinsip 
win-lose solution yang mengutamakan persaingan dalam belajar harus diganti dengan win-win solution yang mengutamakan keberhasilan bersama.

Guru sebagai ujung tombak dalam proses pembelajaran dituntut untuk peka terhadap beragam latar belakang peserta didik. Maka, proses pembelajaran yang bersifat multikultural harus menggunakan materi yang mengintegrasikan beragam kultur dan kondisi sosial ekonomi. Pengadopsian materi tanpa melihat konteks dan kultur masyarakat penerimanya akan berakibat buruk bagi kemajuan belajar siswa. Demikian pula, metode pembelajaran bervariasi karena disesuaikan dengan karakteristik dan cara berpikir (proses memperoleh pengetahuan) yang beragam. Teori-teori multikultural menegaskan bahwa nilai-nilai, sejarah pribadi, sikap-sikap dan keyakinan seseorang tidak dapat dipisahkan dari pengetahuan yang dihasilkannya (Zamroni, 2008: 205). Di dalam suatu komunitas etnik terkandung sistem pengetahuan yang diwariskan turun-temurun yang mempengaruhi cara berpikir mereka, baik ketika berada di komunitasnya maupun di sekolah. Hal-hal tersebut harus dipahami betul oleh guru agar tidak mudah berprasangka terhadap peserta didiknya yang berakibat pada hubungan yang kurang harmonis.

Proses pembelajaran merupakan kurikulum dalam praksis. Dengan demikian keduanya tidak dapat dipisahkan. Kurikulum di Indonesia yang berlaku sekarang dinamakan Kurikulum Tingkat Satuan Pendidikan (KTSP). Kurikulum ini sebenarnya sudah bersifat multikultural. KTSP sangat berpeluang mewujudkan tujuan pendidikan multikultural karena kurikulum ini benar-benar berpihak kepada peserta didik dalam konteks sosial-budaya dan kehidupan sehari-hari. Pengalaman belajar dikontekstualisasikan dengan kebutuhan setempat.

Ditinjau dari aspek ekonomi, sebagian besar orang Indonesia adalah orang miskin. Secara demografis mereka lebih banyak terdapat di luar Jawa dan tinggal di pedesaan. Kemiskinan menghambat orang untuk dapat mencapai kesetaraan pendidikan dan peluang untuk sukses. Lingkaran kemiskinan merupakan lingkaran setan yang sulit sekali untuk diputus rantainya. Maka, pendidikan multikultural di Indonesia harus diprioritaskan pada upaya mengangkat peserta didik dari kelompok miskin agar mereka lebih berdaya dalam kehidupannya, dibandingkan keluarga atau masyarakatnya. KTSP memberi peluang besar untuk mencapai tujuan tersebut. Misalnya, dalam konteks suku Asmat yang tinggal di daerah berawa-rawa, dapat 
dirancang pembelajaran untuk pemberdayaan mereka dalam teknologi sederhana untuk dapat menguasai alam sekitarnya, khususnya sungai serta pengelolaan sumber daya air dan laut. Demikian pula, anak-anak di Langsa, Aceh Timur perlu belajar mengolah hasil laut, khususnya ikan dan rumput laut, yang selama ini belum tergarap, sedangkan anak-anak Halmahera sangat perlu mengembangkan kesenian tradisional dan penyelidikan flora dan fauna (Indratno, 2007:107-108). Anak-anak SMP di Turi, Sleman mengembangkan kemampuan bertanam salak. Memang dalam kenyataannya ada sebuah SMP di sana yang mempunyai kebun salak. Kebun ini menjadi kebun percobaan untuk siswa-siswanya. Dari proses ini, anak-anak mengembangkan pengalaman belajar yang sesuai dengan kebutuhan hidup dan masyarakatnya. Di sini kreativitas dan keberpihakan guru menjadi sangat penting. Sekolah bisa menjadi arena anak-anak untuk membentuk habitus (kebiasaan) baru, tanpa didominasi oleh kepentingan untuk menonjolkan budaya yang dipandang main-stream.

Selain itu, di dalam KTSP terdapat komponen kurikulum muatan lokal. Dikaitkan dengan tujuan pendidikan multikultural, muatan lokal di tingkat SMP dapat dipandang sebagai suatu antisipasi untuk anak-anak SMP yang tidak dapat melanjutkan ke SMA atau SMK. Anak-anak SMP yang tidak dapat melanjutkan pendidikan ke jenjang yang lebih tinggi sangat banyak di negara kita, baik karena terkendala masalah biaya maupun faktor geografis yang sangat sulit/terpencil. Dengan kurikulum muatan lokal di tingkat SMP, mereka tetap memiliki kompetensi di bidang tertentu terkait dengan kecakapan hidup yang bersifat praktis dan bermanfaat ekonomis bagi dirinya dan masyarakatnya. Bila budidaya rumput laut dimasukkan menjadi mata pelajaran muatan lokal di suatu pulau terpencil di Indonesia, misalnya di pulau Natuna, maka diasumsikan setelah lulus mereka dapat langsung mandiri dengan menjadi petani rumput laut. Atau bila SMP berada di daerah pegunungan, mereka dapat menjadi petani sayur-mayur yang berhasil bila telah diperkenalkan budidaya pertanian yang memenuhi standar, bila perlu standar internasional agar mereka dapat turut serta dalam kegiatan ekspor hasil pertanian.

Selain muatan kurikulum lokal yang memberi penekanan pada ketrampilan dan kecakapan hidup, mereka juga perlu dibekali dengan muatan lokal yang menanamkan semangat kewirausahaan. Para siswa perlu dibekali dengan latihan 
mental untuk tetap mempunyai semangat pantang menyerah, bertindak kreatif dan produktif dalam bekerja dengan memperhatikan efisiensi dan efektifitas internal.

Dengan demikian dapat dikatakan bahwa proses pembelajaran yang bersifat multikultural untuk Indonesia saat ini lebih diprioritaskan pada upaya memberdayakan kaum termarginalkan ini dari sisi ekonomi, tanpa melupakan sisi yang lainnya. Proses pembelajaran diupayakan agar mencapai paradigma aksi, bukan sekedar akumulasi pengetahuan teoritis yang pasif. Peserta didik diajak berdialog untuk membangun kesadaran kritis yang berujung pada aksi pemberdayaan, bukan pembelengguan.

\section{Penutup}

Dari pemaparan di atas dapat ditarik kesimpulan sebagai berikut:

Pendidikan multikultural di Indonesia didasarkan pada filsafat bangsa yaitu Pancasila yang disepakati oleh para pendiri negara dengan semangat multikulturalisme yang terpancar dalam rumusan sila-silanya. Pendidikan multikultural di Indonesia yang dapat dipandang sebagai model pendidikan terpadu dengan melakukan proses transformasi dalam kultur sekolah, manajemen sekolah dan proses pembelajaran. Kultur sekolah yang sehat perlu dibangun dengan jalan menumbuhkan rasa bangga dengan sekolah, menjalin komunikasi efektif di antara warga sekolah, mensosialisasikan visi dan misi sekolah dengan berulang-ulang dan beragam media, mengadakan kegiatan bersama yang melibatkan kerjasama guru dan siswa.

Manejemen sekolah yang dilandasi tujuan pendidikan multikultural mensyaratkan kepala sekolah sebagai pemimpin (leader) daripada sekedar manajer, yaitu pemimpin yang peka terhadap perubahan dan kemendesakan, menciptakan koalisi, dan menancapkan pendekatan baru dalam budaya sekolah agar siswa yang berasal dari latar belakang sosial, ekonomi dan budaya yang kurang beruntung dapat mencapai kesuksesan dalam belajar. Proses pembelajaran yang berpegang pada prinsip multikultural didasarkan pada pedagogik transformatif, yaitu pedagogik yang mengungkapkan kebebasan dan keterbatasan manusia sekaligus mengakui dirinya adalah makhluk Tuhan Yang Maha Esa. Pedagogik transformatif menekankan pada kerja sama, toleransi, saling menghormati dan sukses bersama, bukan pada 
persaingan dan kemenangan individual. Guru dituntut untuk lebih peka terhadap beragam latar belakang kultur,etnis, sosial-ekonomi peserta didiknya sehingga dapat mengintegrasikan materi sesuai konteks budaya dan konstruksi pengetahuan siswa yang beragam tersebut untuk kemajuan belajar mereka.

Kurikulum Tingkat Satuan Pendidikan (KTSP) mempunyai semangat pendidikan multikultural, karena memberikan keleluasaan sekolah dan guru dalam implementasinya yang disesuaikan dengan konteks sosio-budaya setempat yang arahnya pada pemberdayaan masyarakat. Prioritas utama tujuan pendidikan multikultural di Indonesia harus diarahkan pada upaya mengangkat peserta didik dari kelompok miskin dan terpencil membekali mereka dengan pengetahuan dan ketrampilan yang berguna (life skills) agar lebih berdaya dalam hidupnya.

\section{DAFTAR PUSTAKA}

Gribb, Robert. 2002. "Bangsa: Menciptakan Indonesia” dalam Indonesia beyond Soeharto. Editor: Emmerson, Donald. Jakarta: Gramedia.

Gvosdev, Nikolas. 2008. "Managing pluralism: The human rights challenge of the new century" dalam Multicultural education: Philosophy, policy and practice. Vol. 1 Yogyakarta: Graduate Program The State University of Yogyakarta.

Indratno, A. Ferry T. 2008. Kurikulum yang mencerdaskan. Jakarta: Penerbit Kompas

Kotler, John P. 1996. Leading Change. Boston, Massachussets: Harvard Business School Press.

Kozol, Jonathan. 2000. "From savage inequalities: Children in America's School" dalam Notable selection in multicultural education. Editor Jana Noel. Montana State University: Dushkin/McGraw Hill. 
Syafrudin Bahar, dkk. (ed.). 1995. Risalah sidang-sidang BPUPKI dan PPKI $28 \mathrm{Mei}$ - 22 Agustus 1945. Jakarta: Sekretariat Negara.

Tilaar, H.A. R. 2002. Perubahan sosial dan pendidikan. Jakarta: Grasindo.

2004. Multikulturalisme - tantangan-tangan global masa depan dalam transformasi pendidikan nasional. Jakarta: Grasindo.

Tony Bush And Les Bell (ed.) 2007. Principles and practice of educational management, London: Paul Chapman Publishing.

Undang-Undang Nomor 20 Tahun 2003 tentang Sistem Pendidikan Nasional.

Zamroni. 2008. Several aspect of multicultural education. Yogyakarta: Graduate Program The State University of Yogyakarta. 